\author{
Joanna Siekiera
}

\title{
European Union Policy towards the Pacific Island States
}

\section{The underestimated relations between Europe and the Pacific}

The European Union, as one of the most influential partners in geopolitics, tries to maintain close relations with all continents and regions worldwide. The scope and range, as well as the forms and methods of building multilateral linkages by Brussels vary. Areas such as diplomacy, international law, private business or global economics are, in fact, treated differently vis-à-vis each particular partner. There is no doubt that the Pacific region is not top of the European Union's list of partners. Additionally, the scale and rate of collaboration both in politics and economics with the Pacific has been relatively insignificant up to now. Therefore, any legal or extrajudicial means of cooperation with the Pacific island states will definitely differ from the measures taken by Brussels in relation to China, the United States of America (USA) or certain international organizations, like the Association of South-East Asian Nations or the World Trade Organization. Nonetheless, EU representatives, along with the Members States themselves, are strongly aware of the increasing importance of the South Pacific region. The most recent document, issued by the European Commission in June 2012, was the Joint Communication- Towards a renewed EU-Pacific development Partnership, preceded by the Joint Communication- EU Relations with the Pacific Islands - A Strategy for a Strengthened Partnership from 2006. There have also been some statements published by the European institutions as instantaneous responses to situations in individual South Pacific states, which will be presented in the following part of this paper.

The European Union's relationship with the island states in the South Pacific is an unfamiliar and highly specialised subject, which is why this area has been the focus of insufficient analysis. There are few professionals dealing with the process and forms of bilateral cooperation between Europe and the Pacific ${ }^{1}$, especially when it comes to the

1 By the term „Pacific”, the author means here the region of the South Pacific Ocean which covers three subregions: Micronesia, Polynesia and Melanesia. Such a definition is far from the 
legal terms. It is worth emphasising that according to Western experts, the Pacific area has an increasing role in the geopolitics of the 21 st century. In the late 80 s, when the process of regionalisation in the subcontinent started to be formalized ${ }^{2}$, a motto was launched "The Pacific Century". Under the slogan, statistics are gathered and analyses are made by politicians, businessmen, academics and journalists to defend the thesis that the Pacific region will finally become a politically and economically significant partner in the 21st century ${ }^{3}$. The world's attention is nowadays focused mostly on South East Asia, neglecting at the same time the more numerous United Nations Member States in the Pacific ${ }^{4}$. What is necessary to add is that the region is evidently achieving primacy in geopolitical domination, while the Micronesian, Polynesian and Melanesian states are no longer isolated parties. They might de facto and de iure (after achieving international legal status as sovereign states), become new international business partners. What those entities can provide in return are attractive markets along with unexploited resources.

The countries of these two continents are part of the same western civilisational and legal culture. The island states are former colonies of the European metropolis, therefore they are more connected with EU members than with any Asian hyper-economy. What is more, they recognise their shared values and historical, political, economic and cultural ties. From the legal point of view, these groups of states have a high respect for the promotion of human rights and fundamental freedoms, democracy and the rule of law. They are aware of the need for heightened and efficient global and regional cooperation, mainly through the United Nations (UN), following the purposes and principles of the Charter.

common understanding of the Pacific region as part of the Asian continent. It appears obvious that EU relations with the tycoons of Asia are on a high and well-developed level while collaboration with the Pacific island states remains neglected.

2 More about the phenomenon of regionalisation in the South Pacific see: J. Siekiera, International Cooperation among States in the South Pacific Region, in: "Folia Iuridica Wratislaviensis" vol. 2, no. 2/2013, University of Wrocław, Wrocław 2013.

3 "The Pacific Century" concept illustrates the expected and desired course of international relations in the 21st century on the Pacific Ocean, that is where world powers and the former colonial metropolis are extending their influences. According to the former Ambassador to Belgium, Luxembourg, the EU and NATO, Brendan Nelson: "Five of the world's economic powerhouses are in the Asia Pacific - US, China, India, Japan and the Republic of Korea" in: Europe and the Asia Pacific, in "Policy Briefs" No. 010/2012. More on this topic: S. Terry, Where the wave of the future will crest? in: "The Christian Science Monitor", 28.09.1982; H. Clinton, America's Pacific Century, in: "Foreign Policy" 11.11.2011; D. Rumley, The Geopolitics of AsiaPacific Regionalism in the 21st Century, in: "The Otemon Journal of Australian Studies" 2005, vol. 31, p. 5-27.

4 Interview with D. Zdziech, chairman of the Polish Association ANZORA (Australia, New Zealand and Oceania Research Association), Cracow 15.03.2013.

5 The purposed and principles of the United Nations are written in the 1st chapter of the Charter of UN from 26 June 1945. Compare those values with the chapeau of the European Union - 


\section{European Union cooperation programs aimed towards the developing island states}

Before the particular programs directed by the European Union towards the Pacific states are presented, it is necessary to pay attention to the Pacific entities' varied forms of international legal status. Without going into details, one needs to be aware of the existence of three groups of countries. These are: 1) fully independent states ${ }^{6}$ : (besides Australia and New Zealand as the largest and most developed countries in the region) Papua New Guinea, the Republic of Fiji, the Solomon Islands and the Republic of Vanuatu from Melanesia, the Republic of Kiribati and the Republic of Nauru from Micronesia and the Independent State of Samoa, the Kingdom of Tonga and Tuvalu from Polynesia; 2) dependent states, such as French Polynesia (dependent on France), the Hawaiian Islands (USA), the Eastern Island (Chile) and the Pitcairn Group of Islands (British Overseas Territories); 3) free associated states ${ }^{7}$ : the Republic of Palau, the Federated States of Micronesia and the Republic of the Marshall Islands (associated with the USA), Niue and the Cook Islands (associated with New Zealand). These two latter groups of countries are not independent, therefore they are not entitled to sovereignty nor to maintain their own international relations, such as entering into cooperation with intergovernmental organizations. Consequently, they can function and act on the international arena only through their partner states.

The Delegation of the European Union complements the embassies of the European Union members. This institution, based in $\mathrm{Fiji}^{8}$, has the geographical coverage of the Pacific region (regional organizations like the CROP agencies ${ }^{9}$ ), the Pacific sovereign states (so-called Pacific countries of the African, Caribbean and Pacific Group, P-ACP) and Overseas Countries and Territories, OCT. The Delegation provides and manages external assistance, on the basis of the EU budget and the European Development Fund,

Australia Partnership Framework adopted at the annual Foreign Ministers' on 29 October 2008.

6 In accordance with art. 1 of the Montevideo Convention on the Rights and Duties of States from 26 December 1933.

7 This specific international legal status can be chosen on the basis of e principle VI of the UN Resolution 1541 (XV) adopted on the Fourth Committee on 15 December 1960.

8 There are also other Delegations of the EU in the South Pacific: the EU Delegation in Papua New Guinea, East Timor, Solomon Islands, Vanuatu and New Caledonia and Samoa. More about the institutional framework of those delegations: website of the delegations of the EU in the Pacific: http://eeas.europa.eu/delegations/fiji/eu_pacific/political_relations/ institutional_framework/index_en.htm.

9 Council of Regional Organisations in the Pacific (CROP) is a family of agencies occupied by progressing and facilitating human development of the islands states, established in 1988. Websites of the Pacific Islands Forum: http://www.forumsec.org/pages.cfm/about-us/crop;website of the Secretariat of the Pacific Community: http://www.sopac.org/index.php/crop. 
which will be introduced later in this paper ${ }^{10}$. In 2005 , Brussels undertook grand commitments to increase its aid programmes, as well as to improve the contribution of "non aid policies". The latter procedures include more efficient execution of the Millennium Development Goals (MDG) of the $\mathrm{UN}^{11}$ to meet challenges in developing countries. Additionally, the ACP states and the EU have agreed to enhance the political and legal dimension of their partnership by means of a more systematic and formal dialogue. Such discourse ought to be based on written, binding and executed principles of partnership as well as ownership. Moreover, the political aspect was enlarged to security issues. Other dimensions of cooperation between the two continents are good governance, democratic principles, human rights, and the rule of law, with the aim of being far more constructive and operational ${ }^{12}$.

In 2006, the Communication from the European Commission to the Council, the European Parliament and the European Economic and Social Committee, entitled "EU Relations with the Pacific Islands - A Strategy for a Strengthened Partnership" was issued $^{13}$. This document was established in the context of the EU-ACP Partnership ${ }^{14}$. The Cotonou Agreement signed in 2000, after an amendment in 2010, remains the most comprehensive partnership agreement between 79 developing countries from Africa, the Caribbean, the Pacific and the European Union ${ }^{15}$. Former European Trade Commissioner, Peter Mandelson, said that the EU needed to build a new affiliation with the South Pacific states, which in turn would lead to a strengthening of the region, both in terms of economic and humanitarian development ${ }^{16}$. The two revisions (in 2005 and 2010) of the Agreement introduced, after over 30 years of cooperation, new challenges, such as state fragility, regional integration, aid effectiveness, food security and climate change ${ }^{17}$. The amendments to the text were also necessary from the perspective of enlargement of the EU. The actors in cooperation are mainly states (through their au-

10 Website of the Delegation of the European Union for the Pacific: http://eeas.europa.eu/ delegations/fiji/eu_pacific/political_relations/index_en.htm.

11 More on the eight Millennium Development Goals see: website of the United Nations: http:// www.un.org/millenniumgoals/.

12 Art. 8 of the revised Cotonou Agreement of 2005.

13 Brussels, 29.05.2006, COM 2006248 final.

14 The other informal name is "Cotonou Agreement". The official name of the document is: Partnership Agreement between the members of the African, Caribbean and Pacific Group of States of the one part and the European Community and its Member States of the other part, signed on 23 June 2000 in Cotonou, Bénin.

15 The act is in force until 2020.

16 Statement of EU Trade Commissioner P. Mandelson, April 2007.

17 Compare the original, consolidated text of the Cotonou Partnership Agreement from 2000 and two revisions; official information issued by the European Commission The Cotonou agreement Signed in Cotonou on 23 June 2000, Revised in Luxembourg on 25 June 2005, Revised in Ouagadougou on 22 June 2010, Official Journal of the European Union, 2012. 
thorities and/or organisations of states) as well as non-state actors (economic and social partners from the private sector, such as trade union organisations, civil society, etc.). It has to be added that all members of the Pacific Islands Forum (PIF) ${ }^{18}$ are parties to the document. Such a comprehensive partnership between Europe and the South Pacific is based on three complementary pillars: development cooperation, economics and trade, as well as the political dimension ${ }^{19}$. Here, it is only worth recalling the trade relations between Brussels and the Pacific region. Exports to the EU from the South Pacific are dominated by coffee, coconut, caviar, fish and palm oil. Imports, in turn, to the Pacific are dominated by electrical machinery and equipment. Overall, trade relations between Brussels and the Pacific island states are on a very small scale both in absolute and relative terms ${ }^{20}$.

Another Joint Communication "Towards a renewed EU-Pacific development Partnership" pronounced in 2012 by the European institutions shows the great concern to establish close relations with "this region [as] an emerging foreign policy priority for both the EU and many of its strategic partners such as the US, Japan, China, Russia and India"21. The European Union, as a global player, aims at renewing and reinforcing the partnership beyond a donor-recipient connection. The funds coming from Brussels to the developing island states are called the European Development Fund (EDF). The first part of the programme took place in the years 1959-1964, while the latest one was indeed the Revised Cotonou Agreement (2008-2013) ${ }^{22}$. The tenth EDF covered an overall budget of 22682 million Euros. The strategy is divided into two focal areas:

18 PIF appears to be the most influential regional organization in the South Pacific, comprising 19 island states. See the website: http://www.forumsec.org.fj/pages.cfm/about-us.

19 Website of the European Commission: http://ec.europa.eu/europeaid/where/acp/overview/ cotonou-agreement/index_en.htm.

20 For more on this subject, see the official EU reports on trade of the European Commission: http://ec.europa.eu/trade/policy/countries-and-regions/regions/pacific/ (20.05.2014). Read the schemes of the programmes presented by non-governmental organizations and branches of the public sector dealing with the aid to non-European countries, like the Pacific Institute of Public Policy with the headquarter in Vanuatu or British think tank, Overseas Development Institute. N. Soni N. and D. Brien, Beyond Fish and Coconuts: Will the New EU Trade Policy Support Development in the Pacific Islands? essay issued by the Overseas Development Institute in 2012; Aid, Trade, Charade? Discussion paper No. 14 by the Pacific Institute of Public Policy, June 2010.

21 Art. 1 of Joint Communication to the European Parliament, the Council, the European Economic and Social Committee and the Committee of The Regions: Towards a renewed EUPacific development Partnership, 2012/06.

22 EDF editions with the appropriated legal basis in the form of an agreement: First EDF: 19591964, Second EDF: 1964-1970 (Yaoundé I Convention), Third EDF: 1970-1975 (Yaoundé II Convention), Fourth EDF: 1975-1980 (Lomé I Convention), Fifth EDF: 1980-1985 (Lomé II Convention), Sixth EDF: 1985-1990 (Lomé III Convention), Seventh EDF: 1990-1995 (Lomé IV Convention), Eighth EDF: 1995-2000 (Lomé IV Convention and the revised Lomé IV), Ninth EDF: 2000-2007 (Cotonou Agreement), Tenth EDF: 2008-2013 (Revised 
Sustainable Management of Natural Resources and Environment, and Regional Economic Integration ${ }^{23}$. The European Development Fund remains the main instrument for providing EU aid for development cooperation with the Pacific ${ }^{24}$.

\section{Legal and extrajudicial measures}

However, two previously mentioned Communications do not possess legally binding power over the forthcoming and indeed desired cooperation between those two continents. The documents themselves, as acts issued by one of the European Union institutions, cannot bind the organization nor any Member State. Therefore, values and norms written in the Communications are only guidelines, advice on which direction the EU is going, as well as guidance for its members. One may charge for the usage of extrajudicial methods and not for so-called hard law means. The latter ones are final, binding and for this reason, states are not willing to apply them to such international duties, which will be executed according to the norms of international law. The soft law measures of cooperation, in turn, like the Communication mentioned above, are less formal, and more suitable and flexible for any party in international relations. They are far quicker to achieve, allowing clever forms of implementation and finally, those methods appear to make things easier when it comes to reaching conclusions. For these reasons, at the beginning of collaboration, when entities are just entering into close cooperation, it is more likely and proper for them to start with non-binding acts ${ }^{25}$.

Relatively, there are many European programs aimed towards the poor, developing island states, including non-binding statements, official warnings and reactions to the situation in the South Pacific region. It is worth mentioning a few of them as it becomes obvious that EU relations with this subcontinent meaningfully differ. "The European Union would like to convey its deepest sympathy and solidarity with the people of

Cotonou Agreement). From the website of the European Commission: http://europa.eu/legislation_summaries/development/overseas_countries_territories/r12102_en.htm (19.05.2014).

23 Regional Economic Integration is also a part of “The Pacific Plan”. Such regional strategy was introduced for strengthening cooperation and integration between the Pacific island countries, in the process of regionalization. The main international organization responsible for this international phenomenon was the PIF, mentioned above. See the website of the Pacific Islands Forum Secretariat: http://www.forumsec.org/pages.cfm/strategic-partnerships-coordination/pacific-plan; the exact data on the funds used in the EDF, see: http://eeas.europa.eu/ delegations/fiji/eu_pacific/political_relations/agreements/index_en.htm.

24 For more detailed information about the programme and the fund, see: Pacific Region European Community Regional Strategy Paper and Regional Indicative Programme for the Period 2008 - 2013, signed in Strasbourg on 15 November 2008; website of the Summaries of the EU Legislation: http://europa.eu/legislation_summaries/development/ overseas_countries_territories/r12102_en.htm.

25 J. Sutor, Leksykon dyplomatyczny, Warsaw 2010, p.104. 
Tonga affected by this natural disaster." said Ambassador Andrew Jacobs from the EU Delegation for the Pacific after channelling European financial aid to the Government of Tonga in April 2014 ${ }^{26}$. Next, Adapting to Climate Change and Sustainable Energy (ACSE) appears to be another unique area of collaboration. In February 2014, the European Union signed a financing agreement with the Pacific Islands Forum Secretariat to help the 15 Pacific ACP countries in adapting to climate change, reducing their reliance on fossil fuels and finally with capacity building ${ }^{27}$. Illegal fishing and illegal purchasing of the national fishing zones is another big problem for the poor island countries ${ }^{28}$. The European Commission, in its official warning issued in June 2014, highlighted that Papua New Guinea was not doing enough to fight against illegal, unreported and unregulated (IUU) fishing, that it lacks a system of sanctions and has deficiencies in controlling and surveillance of fisheries ${ }^{29}$. Last but not least, the European Instrument for Democracy and Human Rights (EIDHR) is the main tool for the promotion of human rights around the world, including Pacific ACP partners. The EU and those island states are engaging in a comprehensive and deep political dialogue on human rights, rules of law and democracy in a global context. The initiative had a €1.1 billion budget in the years 2007-2013. This mechanism is indicative of the EU's conviction that the reduction of poverty is the main goal of its overseas development mission. And for this reason, it will only be achieved in a democratic structure, using legal methods, where human rights are respected and upheld ${ }^{30}$.

\section{Conclusion}

The second decade of the 21st century calls into question fossilized international relations, the primacy of the Euro-Atlantic community and indeed does "pivot" or "rebalance" the world's economic, political and military resources towards the Pacific region ${ }^{31}$.

26 European Union contributes towards rehabilitation work in Tonga, leaflet issued by Secretariat of the Pacific Community, 8.04.2014.

27 European Union and Pacific Islands Forum Secretariat sign a FJ\$90.8m. programme on climate change, Joint Press Release from the European Union and the Pacific Islands Forum Secretariat, 27.02.2014.

28 M. Jędrusik, Wyspy tropikalne; W poszukiwaniu dobrobytu, Warsaw 2005, p.155-159.

29 Commission warns Philippines and Papua New Guinea over insufficient action to fight illegal fishing, Press release by the European Commission, 10.06.2014.

30 Website of the Delegation of the European Union for the Pacific: http://eeas.europa.eu/ delegations/fiji/eu_pacific/political_relations/political_framework/index_en.htm.

31 B. Ghoshal, The Russian Pivot to Asia Pacific, issue brief no. 242 for the South Asian think tank The Institute of Peace and Conflict Studies, November 2013; J. Parello-Plesner, Grading Europe in the Asia-Pacific: European Foreign Policy Scorecard 2013, in: "Asia Pacific Bulletin, No 203, 28.02.2013; H. Takkula, EU relations with Asia-Pacific partners 'increasingly important', "Parliament Magazine” 4.11.2013. 
The South Pacific as a subcontinent, along with its numerous sovereign states, is visibly getting a lead in geopolitical domination. The Micronesian, Polynesian and Melanesian countries are no longer isolated parties in the global arena. Many statistics and analyses indicate the appearance of a new (equally treated - J. S.) international business partner- that is the Pacific. On the other hand, a huge specific of this region, its uniqueness, brings a need for separate treatment. The attractive markets with their unexploited recourses can be additional benefits of possible and very desirable cooperation. The presented European funds, aid policies or strategic schemes are some of the legal frameworks of such inter-continental collaboration. As soon as the European Union agrees on that, the sooner the governments, companies and inhabitants of those two regions will benefit from this unusual cooperation.

\section{SUMMARY}

\section{European Union Policy towards the Pacific Island States}

The article concerns the idea as well as the form of international cooperation between states and international organizations, illustrated by the example of the relationship between the European Union and the Pacific region. There is some useful literature on the subject but this needs be to completed. The influences of the world's leaders collide on the Pacific Ocean, which gives this area primacy in geopolitical domination, slowly downgrading the Atlantic Community. The main purpose of the paper is, therefore, to research the possibilities and methods of legal and extrajudicial cooperation between two continents which are very distant from each other. This work underlines the difference between official policy, presented by the regional intergovernmental organizations, and the individual policies of member states, who are not tied down by Brussels politics and may maintain their own foreign relations.

Keywords: European Union, foreign policy, European Union foreign policy, Pacific, South Pacific, Pacific island 